Article

\title{
Inactivation of Salmonella Typhimurium by Non-Thermal Plasma Bubbles: Exploring the Key Reactive Species and the Influence of Organic Matter
}

\author{
Ki Ho Baek ${ }^{1}{ }^{1}$, Ye Seul Heo ${ }^{1}$, Joo Young Park ${ }^{2}$, Taemin Kang ${ }^{1}$, Yee Eun Lee ${ }^{1}$, Junghyun Lim ${ }^{3}{ }^{\circledR}$, \\ Seong Bong Kim ${ }^{3}$ and Cheorun Jo ${ }^{1, *(1)}$ \\ 1 Department of Agricultural Biotechnology, Center for Food and Bioconvergence and Research Institute of \\ Agriculture and Life Sciences, Seoul National University, Seoul 08826, Korea; kihoback@naver.com (K.H.B.); \\ dptmf_1@naver.com (Y.S.H.); British3616@naver.com (T.K.); esde196@snu.ac.kr (Y.E.L.) \\ 2 Surface Technology Division, Korea Institute of Material Sciences (KIMS), Changwon 51508, Korea; \\ jypark@kims.re.kr \\ 3 Plasma Technology Research Center of National Fusion Research Institute, 37 Dongjangsan-ro, Gunsan-si, \\ Jeollabuk-do 54004, Korea; limjh@nfri.re.kr (J.L.); sbkim@nfri.re.kr (S.B.K.) \\ * Correspondence: cheorun@snu.ac.kr; Tel.: +822-880-4804
}

Received: 11 October 2020; Accepted: 16 November 2020; Published: 18 November 2020

\begin{abstract}
The key reactive species generated by non-thermal plasma bubbles for the inactivation of Salmonella Typhimurium and the effects of organic matter on the inactivation efficacy were investigated. Plasma, which is primarily composed of ozone $\left(\mathrm{O}_{3}\right)$, was generated by dielectric barrier discharge and injected into a solution $(400 \mathrm{~mL})$ as a bubble. The surviving population of $S$. Typhimurium decreased in proportion to the treatment time, resulting in a $5.29 \mathrm{log}$ reduction after $5 \mathrm{~min}$ of treatment. Verification tests to specify key reactive species were conducted using an $\mathrm{O}_{3}$ destruction unit and reactive oxygen species scavengers. The results indicated that singlet oxygen $\left({ }^{1} \mathrm{O}_{2}\right)$ contributes substantially to the inactivation of $S$. Typhimurium, and that the presence of superoxide anion radicals $\left(\mathrm{O}_{2}{ }^{--}\right)$from $\mathrm{O}_{3}$ is essential for the production of ${ }^{1} \mathrm{O}_{2}$. When a $S$. Typhimurium suspension containing organic matter (final concentration: $0,0.005,0.05,0.1$, and $0.5 \mathrm{~g} / \mathrm{L}$ ), consisting of beef extract and peptone, was treated with plasma bubbles for $5,10,15,20,25$, and $30 \mathrm{~min}$, respectively, the potential of the plasma bubbles for inactivating $S$. Typhimurium successfully was verified with longer contact time, despite organic matter attenuating the inactivation efficiency in a dose-dependent manner.
\end{abstract}

Keywords: plasma-activated water; Salmonella Typhimurium; ozone; singlet oxygen; superoxide anion radical; organic matter

\section{Introduction}

As the food industry continues to develop, consumers are demanding safer, fresher, and higher-quality foods [1]. However, despite technological advances, food products can still become contaminated with pathogenic bacteria at any point from production to final consumption, including farming, harvesting, processing, transportation, and storage, which can cause serious health problems and global economic losses [2,3]. Therefore, it is necessary to develop a technology that can effectively inactivate pathogenic microorganisms without compromising food quality. In this regard, it is important to prevent food spoilage in advance and reduce the risk of food poisoning through proper cleaning and sanitization [4]. Many previous studies have been conducted to develop effective sanitizers and disinfectants by utilizing various substances, including chlorine-containing chemicals [5,6], electrolyzed water $[7,8]$, organic acid [9-11], ozone $\left(\mathrm{O}_{3}\right)[12,13]$, and plasma-activated solutions [14-16], and studies have verified that these substances can effectively inactivate microorganisms. Among the various 
disinfectants, plasma-activated water (PAW) has attracted significant attention due to its properties, which include virus inactivation, wound healing, the promotion of plant growth, and microbial inactivation [17].

PAW, which is easy to operate, safe, and highly efficient [11], is usually produced by the treatment of non-thermal (non-equilibrium, cold) plasma in water. Various reactive molecules, commonly called reactive oxygen and nitrogen species (RONS), can be formed by gas-phase discharges and can dissolve or penetrate the liquid (at the gas-liquid interface) to produce secondary reactive species [18]. Secondary aqueous RONS, such as hydroxyl radicals $(\cdot \mathrm{OH})$, hydrogen peroxide $\left(\mathrm{H}_{2} \mathrm{O}_{2}\right)$, singlet oxygen $\left({ }^{1} \mathrm{O}_{2}\right)$, superoxide anion/perhydroxyl radicals $\left(\mathrm{O}_{2}{ }^{-} / \mathrm{HO}_{2}{ }^{\circ}\right), \mathrm{O}_{3}$, nitrite/nitrate $\left(\mathrm{NO}_{2}{ }^{-} / \mathrm{NO}_{3}{ }^{-}\right)$and peroxynitrites/peroxynitrous acid $\left(\mathrm{ONOO}^{-} / \mathrm{ONOOH}\right)$, can initiate chemical and biocidal processes in the liquid [19]. Each reactive species has a different oxidative potential and lifetime [20], and the type and concentration of the reactive species produced in the liquid depend on the discharge conditions, gas types, solution types, etc. [17]. In this regard, PAW can be considered in two aspects, depending on the application method: (1) short- and long-lived reactive species, which are generated in the liquid at the same time as plasma treatment, react with the target in real-time, and (2) short- and long-lived reactive species, which are produced and remain in the liquid during plasma treatment (mainly long-lived reactive species) and newly-generated by post-discharge reactions after plasma treatment, are used separately to react with the target. In fact, Ma et al. demonstrated that short-lived reactive species can also be subsequently produced after discharge through the following reactions (Reactions (1)-(5)) [21]. Therefore, it is important to consider appropriate PAW generation and application methods, depending on the purpose.

$$
\begin{gathered}
\mathrm{ONOOH}+\mathrm{H}_{2} \mathrm{O}_{2} \rightarrow \mathrm{O}_{2} \mathrm{NOOH}+\mathrm{H}_{2} \mathrm{O} \\
\mathrm{O}_{2} \mathrm{NOOH} \rightarrow \mathrm{O}_{2} \mathrm{NOO}^{-} \\
\mathrm{O}_{2} \mathrm{NOO}^{-} \rightarrow{ }^{1} \mathrm{O}_{2}+\mathrm{NO}_{2}^{-} \\
\mathrm{O}_{2} \mathrm{NOO}^{-} \rightarrow \mathrm{NO}_{2}+\mathrm{O}_{2}^{-} \\
2 \mathrm{O}_{2}^{-}+2 \mathrm{H}^{+} \rightarrow{ }^{1} \mathrm{O}_{2}+\mathrm{H}_{2} \mathrm{O}_{2}
\end{gathered}
$$

Since most reactive species have a significantly short half-life and can react with a variety of organic substances (Table 1) [22], there are some possible limitations to the effective pasteurization of bacteria present on food surfaces or in solutions containing organic matter [4], as can be found in other sanitizers or disinfectants [23,24]. To overcome some of these limitations, previous studies have aimed to improve the efficiency of plasma treatment for solutions by incorporating plasma into

\begin{tabular}{|c|c|c|c|c|}
\hline Property & Hydroxyl Radical & Singlet Oxygen & Superoxide & Hydrogen Peroxide \\
\hline $\begin{array}{c}\text { Half-life } \\
\text { (in biological system) }\end{array}$ & $1 \mathrm{~ns}$ & $1 \mu \mathrm{s}$ & $1 \mu \mathrm{s}$ & $1 \mathrm{~ms}$ \\
\hline $\begin{array}{c}\text { Penetration depth } \\
\text { (diffusion coefficient } 10^{-9} \mathrm{~m}^{2} / \mathrm{s} \text { ) }\end{array}$ & $1 \mathrm{~nm}$ & $30 \mathrm{~nm}$ & $30 \mathrm{~nm}$ & $1 \mu \mathrm{m}$ \\
\hline $\begin{array}{l}\text { Reacts with: } \\
\text { Lipids } \\
\text { Carbohydrates } \\
\text { Proteins }\end{array}$ & $\begin{array}{l}\text { Rapidly } \\
\text { Rapidly } \\
\text { Rapidly }\end{array}$ & $\begin{array}{c}\text { Polyunsaturated fatty acids } \\
\text { No } \\
\text { Trp, His, Tyr, Met, Cys }\end{array}$ & $\begin{array}{c}\text { Hardly } \\
\text { No } \\
\text { Fe-S centers }\end{array}$ & $\begin{array}{l}\text { Hardly } \\
\text { No } \\
\text { Cysteines }\end{array}$ \\
\hline
\end{tabular}
various technologies [25-27], one of which involves using bubbles as a potential means of improving the efficiency of mass transfer $[28,29]$. However, few studies have revealed the clear pasteurization mechanism of plasma bubbles.

Table 1. Basic properties of reactive oxygen species in plant tissues (adapted from [22]).

In this study, a non-thermal plasma bubble was applied for the direct plasma treatment of liquid, and $S$. Typhimurium was used as a model pathogenic bacterium. The inactivation efficacy of 
plasma bubbles against $S$. Typhimurium was examined, and the mechanism of its bactericidal action was investigated by exploring the key reactive species in PAW. In addition, the effects of organic matter on the $S$. Typhimurium inactivation efficiency of plasma bubbles were investigated.

\section{Materials and Methods}

\subsection{Plasma Generator and Plasma-Bubbling System}

Figure 1 shows a schematic diagram of the dielectric barrier discharge (DBD) plasma generator and plasma-bubbling system used in this study. The DBD apparatus consisted of four aluminum oxide plates $(100 \times 100 \times 0.635 \mathrm{~mm})$ with two nickel-chromium sheets attached back and forth as electrodes (Figure 1A). The major components of the plasma bubbling system included a function generator (Agilent 33500B series; Agilent Technologies, Loveland, CO, USA), high-voltage amplifier (model 5/80; Trek, Inc., Lockport, NY, USA), plasma generator, air pump, air flow controller, and bubbler (SL-03; Sang-A Pneumatic Co., Ltd., Daegu, Korea) (Figure 1B).

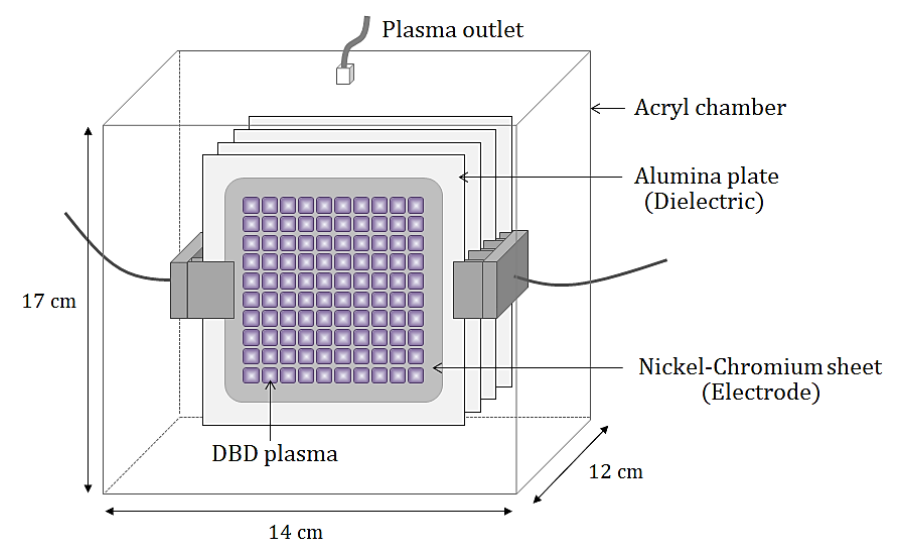

(A)

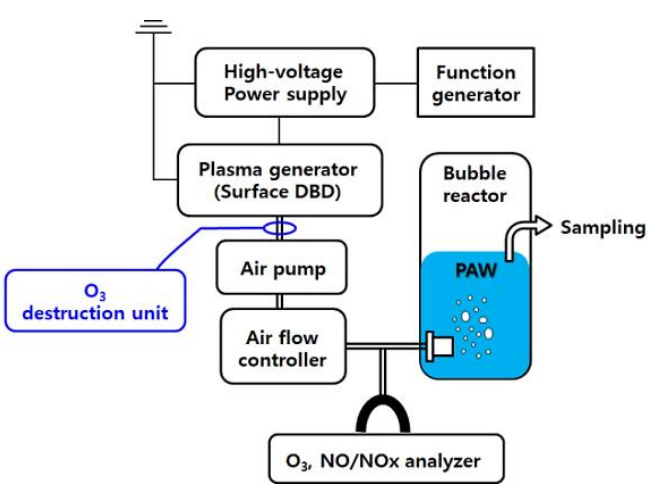

(B)

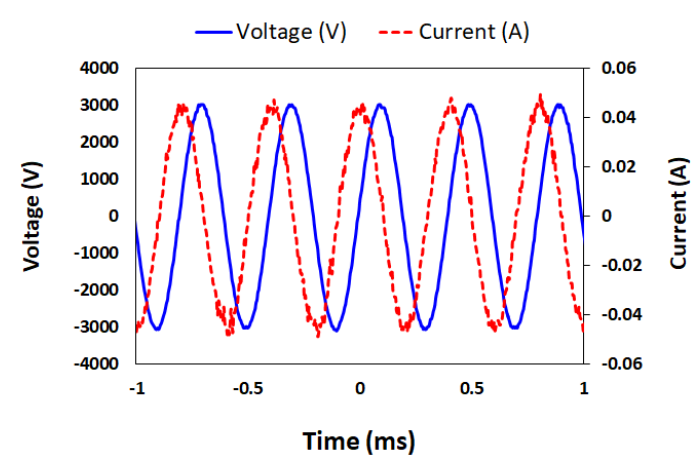

(C)

Figure 1. Schematic diagram of (A) a dielectric barrier discharge (DBD) plasma generator; (B) a plasma-bubbling system $\left(\mathrm{O}_{3}\right.$ destruction unit was optionally applied according to experimental conditions); and (C) voltage and current waveforms during discharge. PAW: plasma-activated water.

\subsection{The Generation of Plasma Bubbles}

Table 2 shows the operating conditions for generating the plasma bubbles used in this study. Plasma was generated between two electrodes separated by an aluminum oxide plate (Figure 1A) and was injected into deionized water $(400 \mathrm{~mL})$ at a gas flow rate of $4 \mathrm{~L} / \mathrm{min}$ through a bubbler. The specific voltage and current waveform generated from the DBD are presented in Figure 1C. Voltage and current profiles were obtained using a digital oscilloscope (DPO 2024, Tektronix, Beaverton, OR, USA) 
equipped with a voltage probe (P6015A, Tektronix, Beaverton, OR, USA) and current probe (Pearson 411, Pearson Electronics, Inc., Pal Alto, CA, USA).

Table 2. Operating conditions for generating plasma bubbles.

\begin{tabular}{cc}
\hline Parameter & Conditions \\
\hline Frequency & $2.5 \mathrm{kHz}$ \\
Peak voltage & $3.0 \mathrm{kV}$ \\
Working gas & Air \\
Gas flow rate & $4 \mathrm{~L} / \mathrm{min}$ \\
Electrode composition & Nickel-chromium \\
Dielectric composition & Aluminum oxide \\
Bubble reactor composition & Acryl \\
Sample volume & $400 \mathrm{~mL}$ \\
\hline
\end{tabular}

\subsection{Measurement of Gaseous $\mathrm{O}_{3}$ and Nitrogen Oxides (NO/NOx)}

To measure the actual amount of gaseous reactive species injected into the bubble reactor, the gas generated under the same operating conditions was collected and analyzed just before the gas was injected into the bubble reactor. The concentrations of gaseous $\mathrm{O}_{3}$ and $\mathrm{NO} / \mathrm{NOx}$ were measured using an $\mathrm{O}_{3}$ analyzer (106-M, 2B Technologies, Boulder, CO, USA) and NO/NOx gas analyzer (nCLD 63, Eco Physics AG, Duernten, Switzerland), respectively.

\subsection{Chemical Measurement in PAW}

The chemical properties of PAW were analyzed simultaneously with plasma bubble treatment (0-5 min). Temperature and $\mathrm{pH}$ were measured using a thermometer (YF-160 Type-K, YFE, Hsinchu City, Taiwan) and pH meter (SevenGo, Mettler-Toledo International Inc., Schwerzenbach, Switzerland), respectively. The concentration of dissolved $\mathrm{O}_{3}$ was analyzed using the indigo method (standard method $4500-\mathrm{O}_{3} \mathrm{~B}$ ) [30]. $\mathrm{NO}_{2}{ }^{-}$and $\mathrm{NO}_{3}{ }^{-}$were analyzed using test kits (TNT840, HACH Co., Loveland, CO, USA) and HACH Test 'N Tube Reactor/Cuvette Tubes with NItraVer X Reagent (Chromotropic Acid method), respectively. A spectrophotometer (DR 1900, HACH Co., Loveland, CO, USA) was used to measure $\mathrm{NO}_{2}{ }^{-}$and $\mathrm{NO}_{3}{ }^{-}$. The concentration of ${ }^{1} \mathrm{O}_{2}$ in PAW (0 and 5 min, respectively) was measured using an electron spin resonance spectroscope (JES-X320, Jeol Ltd., Tokyo, Japan). A final concentration of $10 \mathrm{mM} \mathrm{2,2,6,6-tetramethylpiperidine} \mathrm{(TEMP)} \mathrm{was} \mathrm{used} \mathrm{as} \mathrm{a} \mathrm{spin} \mathrm{trap} \mathrm{reagent} \mathrm{for}$ trapping ${ }^{1} \mathrm{O}_{2}$. In addition, to verify the contribution of superoxide anions $\left(\mathrm{O}_{2}{ }^{\cdot-}\right)$ to the production of ${ }^{1} \mathrm{O}_{2}$, the concentration of ${ }^{1} \mathrm{O}_{2}$ in PAW containing $10 \mathrm{mM}$ tiron (a scavenger of $\mathrm{O}_{2}{ }^{-}$) was also analyzed. All scans were carried out with the following instrument settings: sweep range, $7.5 \mathrm{mT}$; microwave power, $1 \mathrm{~mW}$; modulation width, $0.3 \mathrm{mT}$; time constant, $0.03 \mathrm{~s}$; central magnetic field, $336 \mathrm{mT}$; scanning time, $30 \mathrm{~s}$. Each sample was measured three times and averaged. Hyperfine coupling constants of the signal were obtained using isotropic simulation software (Jeol Ltd., Tokyo, Japan).

\subsection{Bacterial Strain and Culture Conditions}

The Gram-negative bacterium S. Typhimurium ATCC (American Type Culture Collection) 13311 used in this study was provided by the Korean Culture Center of Microorganisms (Seoul, Korea). $S$. Typhimurium was cultivated in fresh sterile nutrient broth (NB; Difco, Becton Dickinson Co., Sparks, MD, USA) at $37^{\circ} \mathrm{C}$ with $120 \mathrm{rpm}$ orbital agitation for $24 \mathrm{~h}$. The cells were washed twice with sterile $0.85 \%$ saline solution by centrifugation at $2265 \times \mathrm{g}$ for $15 \mathrm{~min}$ at $4{ }^{\circ} \mathrm{C}$ using a refrigerated centrifuge (UNION 32R, Hanil Science Industrial Co. Ltd., Gimpo, Korea). The pellets were re-suspended in sterile $0.85 \%$ saline solution at a final concentration of $10^{8}$ to $10^{9}$ colony-forming units (CFU)/mL. 


\subsection{Plasma Bubble Treatment of the Bacterial Suspension and Assessment of Bacterial Inactivation}

For the bacterial inactivation assay, sterile deionized water was inoculated by adding a prepared bacterial suspension to a final concentration of $10^{6}-10^{7} \mathrm{CFU} / \mathrm{mL}$. Then, $400 \mathrm{~mL}$ of bacterial suspension was treated with plasma bubbles for 1, 2, 3, 4, and 5 min. After, NB (Difco) consisting of 37.5\% beef extract and $62.5 \%$ peptone by weight was used to evaluate the effect of organic matter on the inactivation efficacy of plasma bubbles against $S$. Typhimurium suspension. Different final concentrations $(0,0.005$, $0.05,0.1$, and $0.5 \mathrm{~g} / \mathrm{L}$ ) of NB-containing bacteria were treated with plasma bubbles for 5, 10, 15, 20, 25, and $30 \mathrm{~min}$, respectively. After treatment, an aliquot $(1 \mathrm{~mL})$ of the sample was immediately transferred to $9 \mathrm{~mL}$ Dey-Engley neutralizing broth (Difco), mixed well, and decimally diluted. To enumerate both uninjured and injured $S$. Typhimurium, the thin agar layer (TAL) method [31] was applied to recover injured cells. The selective and non-selective media used for TAL were xylose lysine deoxycholate agar (Difco) and nutrient agar (Difco), respectively. To prepare TAL plates, solidified selective medium was overlaid with $7 \mathrm{~mL}$ of melted non-selective medium $\left(48^{\circ} \mathrm{C}\right)$, and another $7 \mathrm{~mL}$ of melted non-selective medium was overlaid ( $7+7 \mathrm{~mL}$; two times overlay) after solidification of the first layer. Each diluent $(100 \mu \mathrm{L})$ was plated onto the TAL plates and incubated at $37^{\circ} \mathrm{C}$ for $24 \mathrm{~h}$.

\subsection{Application of Reactive Oxygen Species (ROS) Scavengers and $\mathrm{O}_{3}$ Destruction Unit}

To evaluate the roles of $\cdot \mathrm{OH}, \mathrm{H}_{2} \mathrm{O}_{2},{ }^{1} \mathrm{O}_{2}$, and $\mathrm{O}_{2}{ }^{--}$in the bactericidal action of plasma bubbles, a final concentration of $200 \mathrm{mM}$ D-mannitol (.OH scavenger), $10 \mathrm{mM}$ sodium pyruvate $\left(\mathrm{H}_{2} \mathrm{O}_{2}\right.$ scavenger $)$, $5 \mathrm{mM}$ sodium azide $\left({ }^{1} \mathrm{O}_{2}\right.$ scavenger $), 10 \mathrm{mM}$ L-histidine $\left({ }^{1} \mathrm{O}_{2}\right.$ scavenger $)$, or $10 \mathrm{mM}$ tiron $\left(\mathrm{O}_{2}{ }^{\cdot-}\right.$ scavenger $)$ was added to the bacterial suspension before plasma bubble treatment. The types and concentrations of these scavengers have already been proven to be effective through several previous studies [32-34]. The bacterial suspension with or without scavengers was treated with plasma bubbles for 5 min, and the inactivation rates were determined as described above. In addition, dissolved $\mathrm{O}_{3}$ analysis and bacterial inactivation assays were conducted after artificially removing $\mathrm{O}_{3}$ gas using an $\mathrm{O}_{3}$ destruction unit (ODS-2P, Ozone Solutions, Hull, IA, USA), which can remove up to $1 \%$ of $\mathrm{O}_{3}$ gas, to verify its contribution to the antibacterial action of plasma bubbles.

\subsection{Statistical Analysis}

All experiments were conducted in triplicate. SAS statistical software (version 9.4, SAS Institute Inc., Cary, NC, USA) was used to analyze the data. Student's $t$-test and Tukey's multiple comparison test were used for statistical analyses. Significant differences among the mean values were established at a significance level of $p<0.05$.

\section{Results}

\subsection{Physicochemical Characterization of Plasma}

During discharge, gaseous $\mathrm{O}_{3}$ continuously increased from 0 to 240 ppm over 5 min, whereas NO/NOx did not occur (detection limit: $0.05 \mathrm{ppm}$ ) (Figure 2A). As a result, the dissolved $\mathrm{O}_{3}$ concentration in PAW increased with treatment time, and was $0.11 \pm 0.008$ ppm after 5 min treatment (Figure 2B). On the other hand, after 5 min of plasma bubble treatment, the concentration of $\mathrm{NO}_{2}{ }^{-}$ in PAW was below the detection limit (2.00 ppm) (Figure S1A), and the concentration of $\mathrm{NO}_{3}{ }^{-}$was only $1.39 \pm 0.051 \mathrm{ppm}$ (Figure S1B). During plasma bubble treatment, the liquid temperature and $\mathrm{pH}$ remained at $24.12 \pm 0.032{ }^{\circ} \mathrm{C}$ (Figure 2C) and $6.30 \pm 0.042$ (Figure 2D), respectively, until $5 \mathrm{~min}$. For atmospheric air discharge [21,35], the $\mathrm{pH}$ of the liquid generally decreased during plasma treatment due to the production of $\mathrm{HNO}_{2}$ and $\mathrm{HNO}_{3}$. These molecules release hydrogen ions through deprotonation reactions, thus acidifying water. However, the current DBD condition did not generate enough $\mathrm{NOx}$ to drastically lower the $\mathrm{pH}$ of the water within $5 \mathrm{~min}$ (Figure 2A,D). 


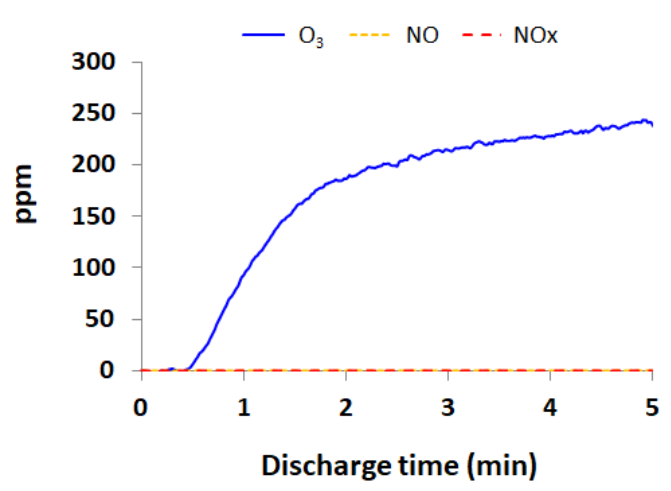

(A)

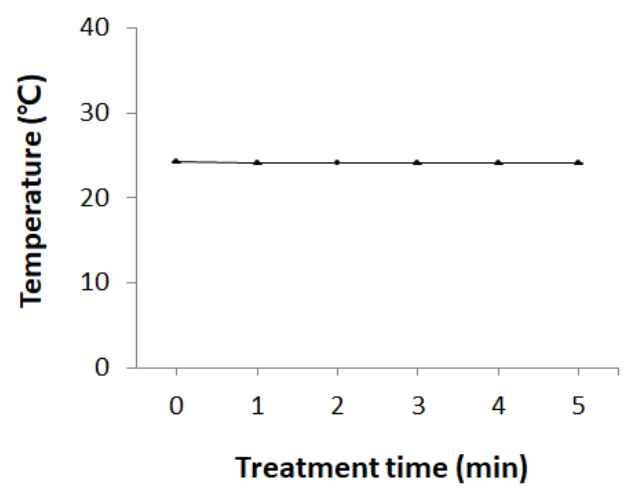

(C)

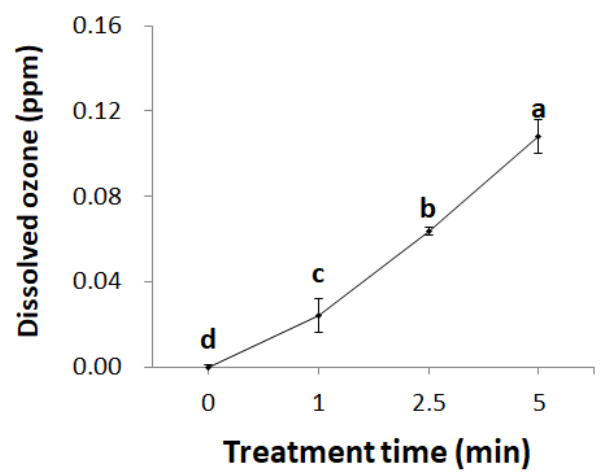

(B)

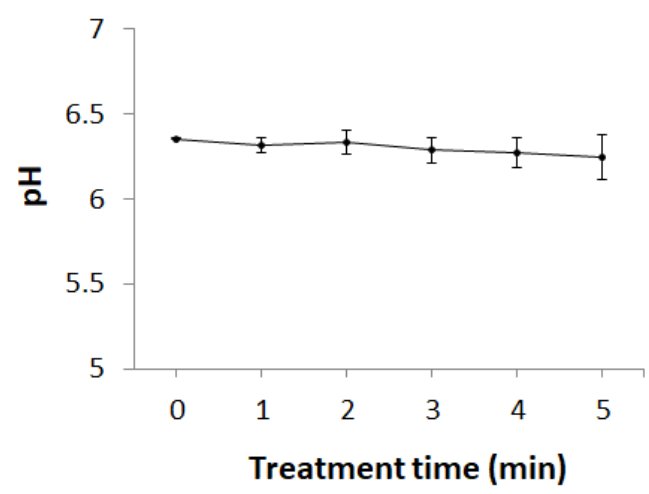

(D)

Figure 2. (A) Gaseous $\mathrm{O}_{3}$ and $\mathrm{NO} / \mathrm{NOx}$ concentrations during discharge; (B) dissolved $\mathrm{O}_{3}$ in $\mathrm{PAW}$; (C) temperature and (D) $\mathrm{pH}$ value of PAW according to the plasma bubble treatment time. Error bars denote standard deviation. ${ }^{\mathrm{a}, \mathrm{b}, \mathrm{c}, \mathrm{d}}$ Different letters indicate significant differences $(p<0.05)$.

\subsection{Bactericidal Effects of Plasma Bubbles and Contributions of Reactive Species}

The inactivation efficacy of plasma bubbles against $S$. Typhimurium is depicted in Figure 3A. The number of viable cells decreased significantly in proportion with the treatment time $(p<0.05)$. The results indicate that plasma bubble treatment effectively inactivated $S$. Typhimurium floating in the solution, and that certain reactive species produced by plasma bubbles contributed to bactericidal action. At this time, ROS should be considered more important than reactive nitrogen species because it has already been verified that the generation and contribution of NOx may be negligible through the results of gaseous NO/NOx concentrations and solutions $\mathrm{pH}$ (Figure 2). Therefore, a series of ROS scavengers, such as D-mannitol for $\cdot \mathrm{OH}$, sodium pyruvate for $\mathrm{H}_{2} \mathrm{O}_{2}$, sodium azide and L-histidine for ${ }^{1} \mathrm{O}_{2}$, and tiron for $\mathrm{O}_{2} \cdot{ }^{\cdot-}$ were used to evaluate the possible roles of plasma bubbles in the bacterial inactivation process (Figure 3B). As a result of the experiment, sodium azide, L-histidine, and tiron almost completely eliminated the bactericidal effects of plasma bubbles. These data suggest that ${ }^{1} \mathrm{O}_{2}$ and $\mathrm{O}_{2}{ }^{--}$were the main functional species of the plasma bubble in the inactivation of $S$. Typhimurium. 


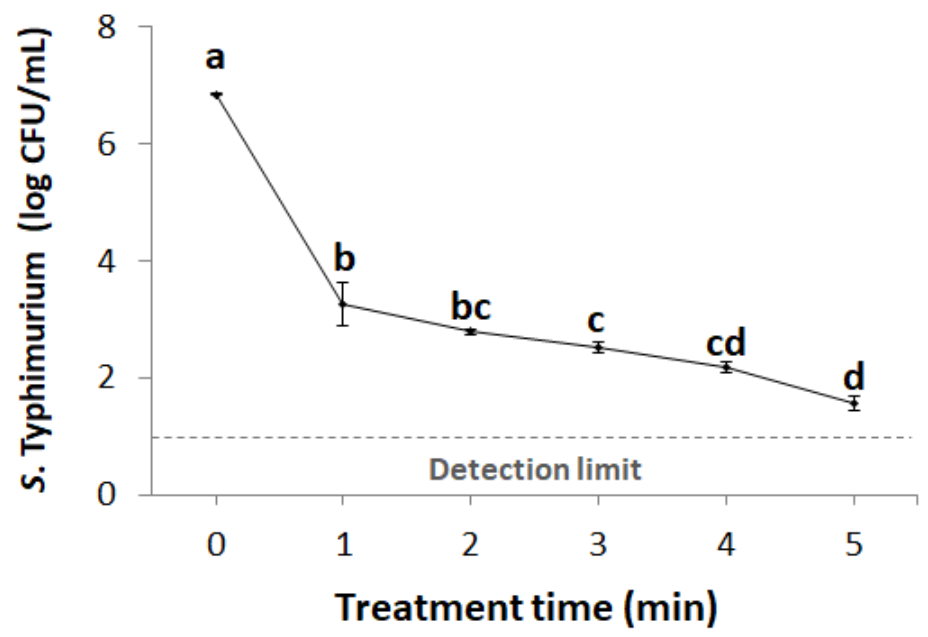

(A)

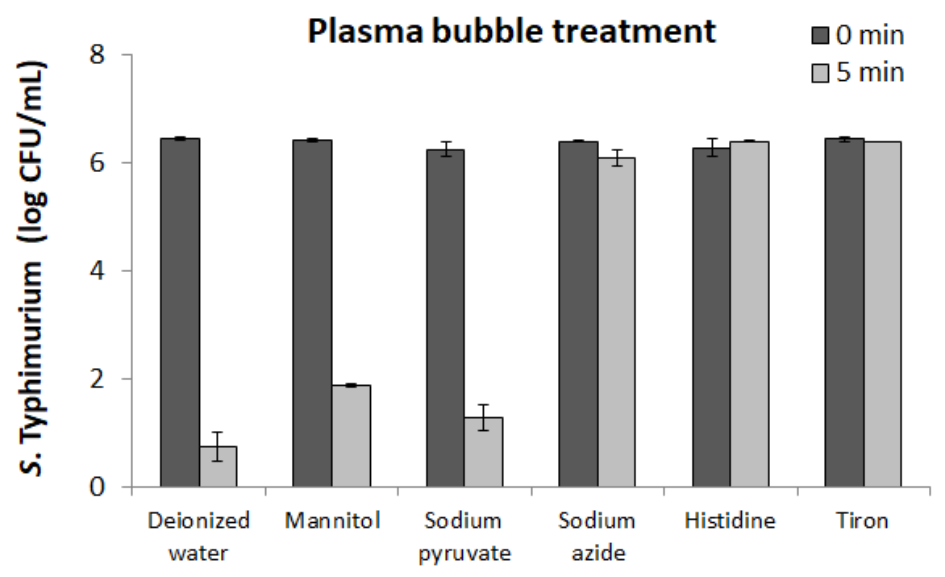

(B)

Figure 3. (A) Surviving population (log colony-forming units (CFU)/mL) of $S$. Typhimurium after different plasma bubble treatment times $(0,1,2,3,4$, and $5 \mathrm{~min})$ and $(\mathbf{B}) \mathrm{S}$. Typhimurium inactivation results by $5 \mathrm{~min}$ plasma bubble treatment with the addition of different reactive oxygen species (ROS) scavengers (D-mannitol for $\cdot \mathrm{OH}$; sodium pyruvate for $\mathrm{H}_{2} \mathrm{O}_{2}$; sodium azide and L-histidine for ${ }^{1} \mathrm{O}_{2}$; tiron for $\mathrm{O}_{2}{ }^{-}$). Error bars denote standard deviation. ${ }^{a, b, c, d}$ Different letters indicate significant differences $(p<0.05)$.

\subsection{The Role of Gaseous $\mathrm{O}_{3}$ on the Bactericidal Action of Plasma Bubbles}

Under the DBD conditions applied in this study, gaseous $\mathrm{O}_{3}$ was produced the most and was injected into the water as a bubble (Figure 2A,B). In the present study, the reactive species contributing most to the bactericidal action of plasma bubbles were ${ }^{1} \mathrm{O}_{2}$ and $\mathrm{O}_{2}{ }^{\cdot-}$ (Figure 3B). Hence, the first consideration was to verify the relationship between gaseous $\mathrm{O}_{3}$ and the key reactive species $\left({ }^{1} \mathrm{O}_{2}\right.$ and $\left.\mathrm{O}_{2}{ }^{-}\right)$. The $\mathrm{O}_{3}$ destruction unit was used to artificially eliminate $\mathrm{O}_{3}$ gas produced from plasma generators, and the concentration of dissolved $\mathrm{O}_{3}$ in solution was measured to assess whether $\mathrm{O}_{3}$ gas was completely removed. Figure $4 \mathrm{~A}$ shows the dissolved $\mathrm{O}_{3}$ concentration in the solution according to the $\mathrm{O}_{3}$ filtration, which confirmed that there was no dissolved $\mathrm{O}_{3}$ in the water under the $\mathrm{O}_{3}$ gas destruction unit during the $5 \mathrm{~min}$ treatment of plasma bubbles. The results of applying the same conditions to $S$. Typhimurium inactivation experiments are presented in Figure 4B. Since the filtration of gaseous $\mathrm{O}_{3}$ completely eliminated the bactericidal action of plasma bubbles against $S$. Typhimurium for 5 min of treatment (Figure 4B), it was confirmed that the production of $\mathrm{O}_{3}$ gas and injection into the solution must precede the inactivation of $S$. Typhimurium by plasma bubbles. 


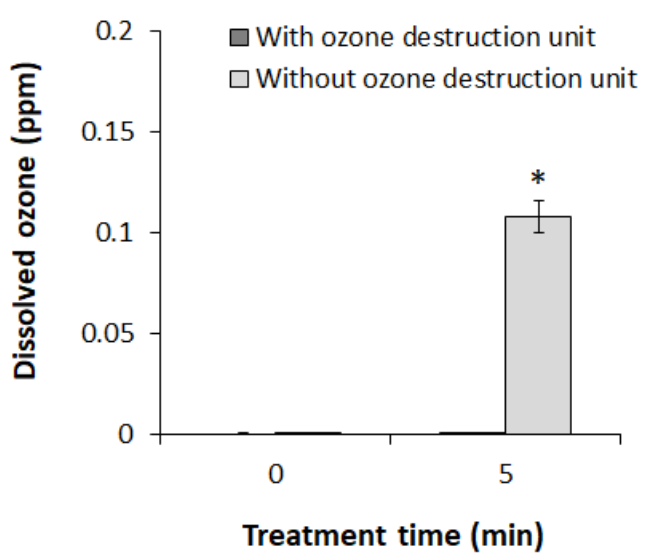

(A)

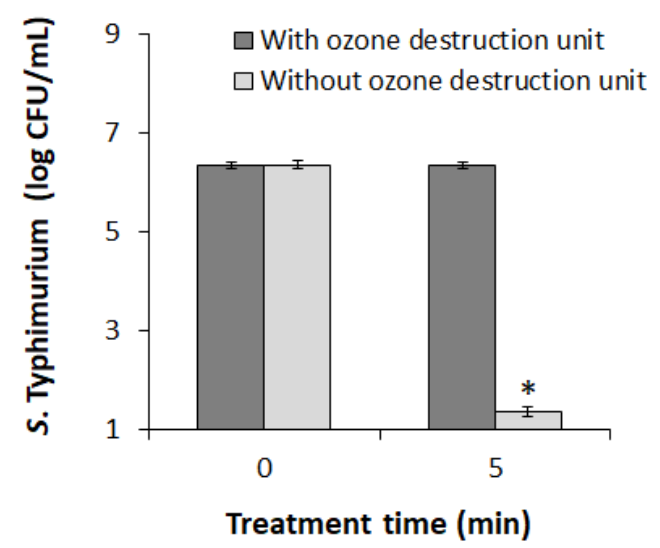

(B)

Figure 4. (A) Concentrations of dissolved $\mathrm{O}_{3}$ in $\mathrm{PAW}$; (B) the surviving population $(\log \mathrm{CFU} / \mathrm{mL})$ of $S$. Typhimurium after 5 min of plasma bubble treatment according to $\mathrm{O}_{3}$ filtration. Error bars denote standard deviation. Student's $t$-test; ${ }^{*} p<0.05$ with respect to the untreated control.

\subsection{Generation of Key Reactive Species by Plasma Bubbles}

The production of ${ }^{1} \mathrm{O}_{2}$ in PAW was analyzed because the role of ${ }^{1} \mathrm{O}_{2}$ in the bactericidal action of $S$. Typhimurium by plasma bubbles is important (Figure 3B). The amount of accumulated ${ }^{1} \mathrm{O}_{2}$ after 5 min of plasma bubble treatment was approximately $168.40 \pm 14.812 \mu \mathrm{M}$ (Figure $5 \mathrm{~A}$ ). Since it was necessary to identify which reactive species mainly contributed to the formation of ${ }^{1} \mathrm{O}_{2}$ during plasma bubble treatment, whether $\mathrm{O}_{2}{ }^{--}$, which plays a role in $S$. Typhimurium inactivation at a level equivalent to ${ }^{1} \mathrm{O}_{2}$, could affect the formation of ${ }^{1} \mathrm{O}_{2}$ was first considered. After 5 min of plasma bubble treatment with the addition of tiron (a scavenger of $\mathrm{O}_{2}{ }^{--}$), it was confirmed that no ${ }^{1} \mathrm{O}_{2}$ was produced in the PAW (Figure 5B). These results indicate that $\mathrm{O}_{2}{ }^{\cdot-}$ is fully involved in the final production of ${ }^{1} \mathrm{O}_{2}$, which, in turn, has a direct effect on $S$. Typhimurium inactivation.

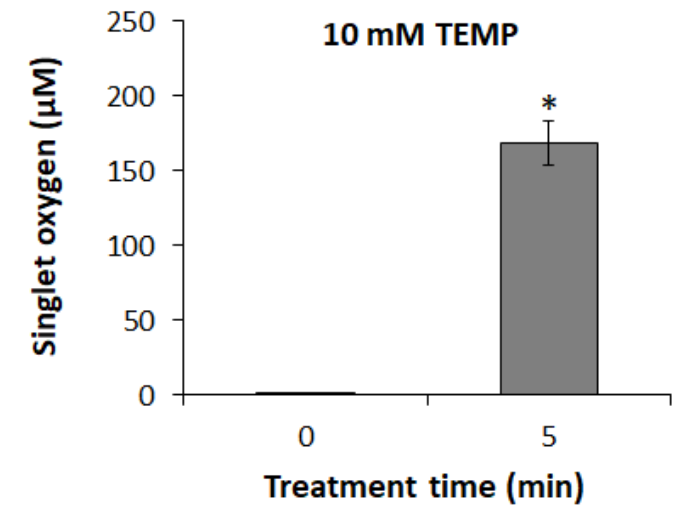

(A)

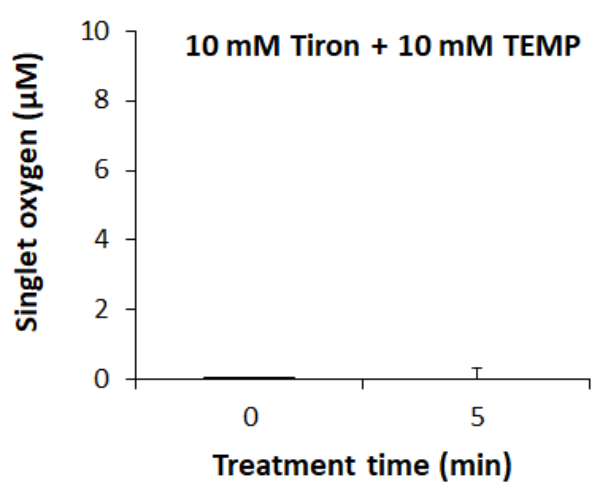

(B)

Figure 5. Concentrations of accumulated ${ }^{1} \mathrm{O}_{2}$ in PAW (A) without or (B) with the addition of $10 \mathrm{mM}$ tiron (a scavenger of $\mathrm{O}_{2}{ }^{-}$) ) during 5 min plasma bubble treatment. TEMP: 2,2,6,6-tetramethylpiperidine (a spin trap reagent for trapping ${ }^{1} \mathrm{O}_{2}$ ). Error bars denote standard deviation. Student's $t$-test; ${ }^{*} p<0.05$ with respect to the untreated control.

\subsection{Effects of Organic Matter on the Inactivation Efficacy of Plasma Bubbles}

The effects of organic matter on the inactivation efficacy of plasma bubbles against $S$. Typhimurium are presented in Figure 6. First, plasma bubble treatment in the absence of organic matter effectively inactivated $S$. Typhimurium, resulting in a reduction of more than $5.86 \log \mathrm{CFU} / \mathrm{mL}$ within $10 \mathrm{~min}$ $(p<0.05)$. On the other hand, $S$. Typhimurium inactivation efficiency in organic mixtures $(0.005-0.5 \mathrm{~g} / \mathrm{L})$ 
according to plasma bubble treatment time decreased as the concentration of organic matter increased. When plasma bubbles were treated for 10 and $20 \mathrm{~min}$ with $0.005 \mathrm{~g} / \mathrm{L}$ organic matter, the surviving population of $S$. Typhimurium decreased by 4.21 and $5.59 \log \mathrm{CFU} / \mathrm{mL}(p<0.05)$, respectively, and no surviving bacteria were detected when treated for more than $25 \mathrm{~min}$ (detection limit: $10^{1} \mathrm{CFU} / \mathrm{mL}$; Figure 6). The bacterial inactivation efficiency of the plasma bubbles after $10 \mathrm{~min}$ of treatment decreased in the $0.05 \mathrm{~g} / \mathrm{L}$ organic matter compared to $0.005 \mathrm{~g} / \mathrm{L}$, but the survival population of S. Typhimurium decreased by 3.06 and $4.77 \log$ CFU $/ \mathrm{mL}(p<0.05)$ as plasma bubbles were treated for 10 and $20 \mathrm{~min}$, respectively, and the bactericidal effect of approximately $5.47 \log \mathrm{CFU} / \mathrm{mL}$ was shown after $30 \mathrm{~min}$ of plasma bubble treatment ( $p<0.05$; Figure 6). However, in organic matter at a $0.1 \mathrm{~g} / \mathrm{L}$ concentration, the inactivation efficiency of the plasma bubbles for $S$. Typhimurium decreased dramatically, and the 10 min treatment of plasma bubbles did not show any significant bactericidal effect. Under the same conditions, the number of $S$. Typhimurium decreased by 1.17, 1.72, and $2.96 \log$ $\mathrm{CFU} / \mathrm{mL}(p<0.05)$, respectively, when plasma bubbles were treated for 20, 25, and $30 \mathrm{~min}$ (Figure 6). When the concentration of organic matter was $0.5 \mathrm{~g} / \mathrm{L}$, the bactericidal effect of the plasma bubbles against $S$. Typhimurium was completely eliminated, and no significant reduction was observed even when the plasma bubbles were treated for up to $30 \mathrm{~min}$ (Figure 6). These results indicate that organic matter severely attenuated the inactivation effect of plasma bubbles against $S$. Typhimurium in a dose-dependent manner.

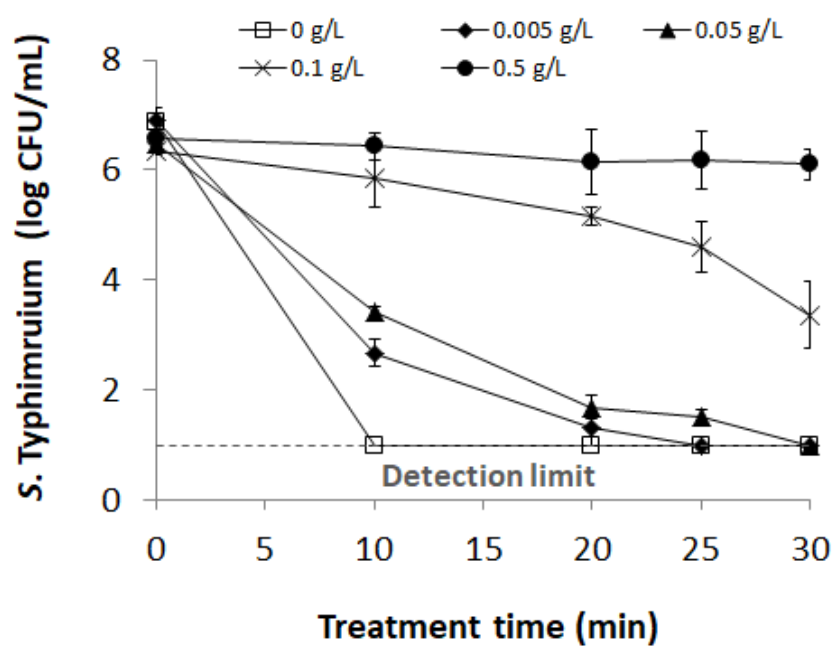

Figure 6. Effects of different concentrations of organic matter (final concentration: 0, 0.005, 0.05, 0.1, and $0.5 \mathrm{~g} / \mathrm{L}$ ) on the inactivation efficacy of plasma bubbles against $S$. Typhimurium according to plasma bubble treatment time $(0,10,20,25$, and $30 \mathrm{~min})$. The organic matter consisted of $37.5 \%$ beef extract and $62.5 \%$ peptone by weight. Error bars denote standard deviation.

\section{Discussion}

In the current study, DBD plasma was applied to inactivate $S$. Typhimurium in suspension, and high concentrations of $\mathrm{O}_{3}$ gases were found to be dominant. At this point, short-lived gas-phase reactive species were excluded, as plasma produced in the plasma generator was injected into the water in a secondary manner. Park et al. reported that the rapidly generated $\mathrm{O}_{3}$ at the early stage of discharge was eventually quenched by $\mathrm{NO}$, resulting in the dominance of $\mathrm{NO}$ and $\mathrm{NO}_{2}$, and that gas temperature $\left(\mathrm{N}_{2}\right.$ vibrational temperature) was one of the important factors in this transition [36]. However, our discharge in air-based surface DBD plasma systems was a condition in which no aforementioned transition occurred, and $\mathrm{O}_{3}$ was mainly formed and acted as a major chemical. Therefore, in this study, as the plasma bubble treatment time increased, the concentration of dissolved $\mathrm{O}_{3}$ in the water increased, eventually pasteurizing $S$. Typhimurium by more than $5 \log \mathrm{CFU} / \mathrm{mL}$ within $5 \mathrm{~min}$. Many studies have been conducted involving the application of $\mathrm{O}_{3}$ generators for the injection of $\mathrm{O}_{3}$ gas into water 
to inactivate microorganisms or decompose organic matter $[13,37,38]$. Since $\mathrm{O}_{3}$ can directly oxidize various organic substances and microbial components [12], previous studies have suggested that concentrations of gas-phase or dissolved $\mathrm{O}_{3}$ in solution are important as oxidative indicators [37,39]. However, not only the concentration of gaseous or aqueous $\mathrm{O}_{3}$, but also the specific reactive species that contribute substantially to the degradation of organic matter or inactivation of microorganisms should be considered. Therefore, verification tests were conducted using an $\mathrm{O}_{3}$ gas destruction unit and various ROS scavengers, which confirmed that ${ }^{1} \mathrm{O}_{2}$ and $\mathrm{O}_{2}{ }^{--}$were the most important reactive species for the direct inactivation of $S$. Typhimurium in the current system.

${ }^{1} \mathrm{O}_{2}$ and $\mathrm{O}_{2}{ }^{--}$are major ROS and have the potential to improve the bactericidal and virucidal effects of PAW [21,33]. Guo et al. reported that ${ }^{1} \mathrm{O}_{2}$ effectively inactivated bacteriophages (doubleand single-stranded DNA as well as RNA bacteriophages) in water by attacking both proteins and nucleic acids, resulting in the aggregation of bacteriophages [33]. Ma et al. also proved that ${ }^{1} \mathrm{O}_{2}$ and $\mathrm{O}_{2}{ }^{--}$induced the antibacterial effects of PAW against Escherichia coli DH5 $\alpha$, and that both species were generated by post-discharge reactions (Reactions (1)-(5)) due to their short half-life [21]. In order for the aforementioned reactions to occur, sufficiently generated $\mathrm{NO}_{2}{ }^{-}$and $\mathrm{H}_{2} \mathrm{O}_{2}$ must react with each other to produce $\mathrm{ONOOH}$, which can further interact with $\mathrm{H}_{2} \mathrm{O}_{2}$ to produce peroxynitric acid $\left(\mathrm{O}_{2} \mathrm{NOOH}\right)$. Finally, $\mathrm{O}_{2} \mathrm{NOOH}$ decomposes into ${ }^{1} \mathrm{O}_{2}$ and $\mathrm{O}_{2}{ }^{-}$. However, in the current system, it is difficult for ${ }^{1} \mathrm{O}_{2}$ or $\mathrm{O}_{2}{ }^{\cdot-}$ to be produced through these reactions because $\mathrm{NO}_{2}{ }^{-}$is not detected in PAW (detection limit: $2.00 \mathrm{ppm}$ ) due to insufficient NOx generation in DBD plasma, and sodium pyruvate (a scavenger of $\mathrm{H}_{2} \mathrm{O}_{2}$ ) does not eliminate the bactericidal effect of plasma bubbles.

In our plasma bubble system, it was confirmed that the injection of $\mathrm{O}_{3}$ gas must precede for generating the source of the antimicrobial action, and the presence of $\mathrm{O}_{2}{ }^{--}$is necessary for the production of ${ }^{1} \mathrm{O}_{2}$. Once $\mathrm{O}_{3}$ enters the water, it becomes highly unstable and rapidly decomposes through a complex series of reactions. At this time, hydroxide ions $\left(\mathrm{HO}^{-}\right)$can initiate a chain reaction, which is sustained by $\mathrm{HO}_{2}{ }^{\circ}$ as follows [40]:

$$
\mathrm{O}_{3}+\mathrm{HO}^{-} \rightarrow \mathrm{HO}_{2}{ }^{\cdot}+\mathrm{O}_{2}^{\cdot-}
$$

The $\mathrm{HO}_{2} \cdot$ generated by the above reaction may initiate further reactions and contribute to the production of ${ }^{1} \mathrm{O}_{2}$. The possible reactions that have been proposed for converting $\mathrm{O}_{2}{ }^{--}$to ${ }^{1} \mathrm{O}_{2}$ are as follows [41]:

$$
\begin{gathered}
\mathrm{HO}_{2}+\mathrm{HO}_{2}^{\cdot} \rightarrow{ }^{1} \mathrm{O}_{2}+\mathrm{H}_{2} \mathrm{O}_{2} \\
\mathrm{HO}_{2}+\mathrm{O}_{2}^{\cdot-}+\mathrm{H}^{+} \rightarrow{ }^{1} \mathrm{O}_{2}+\mathrm{H}_{2} \mathrm{O}_{2}
\end{gathered}
$$

In Reaction (7), two $\mathrm{HO}_{2} \cdot$ molecules react together to produce ${ }^{1} \mathrm{O}_{2}$ (rate constant of $8.6 \times 10^{5} \mathrm{M}^{-1} \mathrm{~s}^{-1}$ ) [41]. Reaction (8) shows the spontaneous dismutation reaction for superoxide, in which $\mathrm{O}_{2} \cdot{ }^{--}$reacts with $\mathrm{HO}_{2} \cdot$ to produce ${ }^{1} \mathrm{O}_{2}$ and $\mathrm{H}_{2} \mathrm{O}_{2}$ (rate constant of $9.7 \times 10^{7} \mathrm{M}^{-1} \mathrm{~s}^{-1}$ ) [41]. As $\mathrm{O}_{2}{ }^{--}$is essential for the production of ${ }^{1} \mathrm{O}_{2}$ in this study, it is worth considering the possibility that the Reaction (8) is the main path for ${ }^{1} \mathrm{O}_{2}$ production. In addition, since the solution $\mathrm{pH}$ remained at $6.30 \pm 0.042$ during the $5 \mathrm{~min}$ plasma bubble treatment, the reaction rate of Reaction (7) is relatively lower than that of Reaction (8) as the $\mathrm{HO}_{2} / \mathrm{O}_{2}{ }^{--}$ratio falls 10 -fold for each unit rise in $\mathrm{pH}$ above a $\mathrm{p} K_{a}$ of 4.8 .

As a result of the current study, the presence of organic matter (beef extract and peptone) in water dramatically attenuated the antibacterial efficacy of plasma bubbles against $S$. Typhimurium. Various sanitizers and disinfectants being less effective in the presence of organic matter, including beef extract, peptone, tryptone, and cellulose, has previously been suggested in a number of studies $[4,23,24]$. Chen et al. demonstrated that organic loads affect the chlorine requirements of produce (romaine lettuce, iceberg lettuce, strawberries, and grapes) wash water, especially as organic loads increase [5]. Jo et al. found that proteins have the greatest negative effect on the antibacterial efficacy of slightly acidic electrolyzed water against Bacillus cereus (ATCC 14579; 10987), Listeria monocytogenes (ATCC 19118 and Scott A), E. coli O157:H7 (ATCC 35150; 43894), and S. enterica (S. Enteritidis ATCC 13076 and S. Typhimurium ATCC 14028) compared to lipids and carbohydrates [24]. Xiang et al. also reported 
that high concentrations of organic matter affected the physicochemical properties of PAW, such as $\mathrm{pH}$, oxidation-reduction potential (ORP), and $\mathrm{NO}_{2}{ }^{-}$, thereby reducing the antibacterial properties of PAW [4]. Similarly, in this study, organic matter attenuated the antibacterial property of plasma bubbles in a dose-dependent manner, but PAW is still highly available because longer contact times have allowed it to eventually successfully inactivate microorganisms (except for at the highest organic matter concentrations).

Particularly for PAW, since reactive species have a remarkably short half-life and can react with a variety of organic materials (Table 1) [22], there are some limitations in the pasteurization of microorganisms present on the surfaces of food or in mixture solutions. To overcome some of these limitations, we applied bubble technology, which has the potential to increase the efficiency of mass transfer [28,29], but unfortunately, the characteristics of bubbles (such as bubble size and density) and the efficiency of mass transfer have not yet been considered in depth.

\section{Conclusions}

This study was conducted to determine the key reactive species generated by non-thermal plasma bubbles for the inactivation of $S$. Typhimurium and to examine the effects of organic matter on inactivation efficacy. Plasma bubble treatment effectively inactivated $S$. Typhimurium floating in water, and ${ }^{1} \mathrm{O}_{2}$ originating mainly from $\mathrm{O}_{3}$ and $\mathrm{O}_{2}{ }^{\cdot-}$ contributed substantially to the bactericidal action. Organic matter attenuated the bactericidal action of plasma bubbles in a dose-dependent manner, but the potential for inactivating $S$. Typhimurium was confirmed successfully with longer contact times. In the future, it will be necessary to consider the types and contents of organic matter contained in the target (solid, semi-solid, or liquid phase) for practical applications in food-related materials, and the specific pasteurization mechanism of plasma bubbles through bubble characterization will need to be identified.

Supplementary Materials: The following are available online at http://www.mdpi.com/2304-8158/9/11/1689/s1, Figure S1: (A) $\mathrm{NO}_{2}{ }^{-}$and (B) $\mathrm{NO}_{3}{ }^{-}$concentrations in plasma activated water after 5 min of plasma bubble treatment. Error bars denote standard deviation. Student's $t$-test; ${ }^{*}, p<0.05$ with respect to the untreated control.

Author Contributions: Conceptualization, C.J. and K.H.B.; methodology, K.H.B., Y.S.H., and J.Y.P.; software, J.Y.P. and J.L.; validation, J.L. and S.B.K.; formal analysis, K.H.B., Y.S.H., T.K., and Y.E.L.; investigation, K.H.B. and Y.S.H.; resources, J.Y.P. and J.L.; data curation, K.H.B. and T.K.; writing-original draft preparation, K.H.B.; writing-review and editing, C.J. and S.B.K.; visualization, C.J.; supervision, C.J. and S.B.K.; project administration, C.J. and K.H.B.; funding acquisition, C.J. All authors have read and agreed to the published version of the manuscript.

Funding: This research was funded by the R\&D Program of 'Plasma Advanced Technology for Agriculture and Food (Plasma Farming)' through the National Fusion Research Institute of Korea (NFRI) funded by government funds.

Acknowledgments: This work was supported by the BK21 Four Program, Seoul National University, Seoul, Korea.

Conflicts of Interest: The authors declare no conflict of interest.

\section{References}

1. Ji, S.H.; Ki, S.H.; Ahn, J.H.; Shin, J.H.; Hong, E.J.; Kim, Y.J.; Choi, E.H. Inactivation of Escherichia coli and Staphylococcus aureus on contaminated perilla leaves by Dielectric Barrier Discharge (DBD) plasma treatment. Arch. Biochem. Biophys. 2018, 643, 32-41. [CrossRef]

2. Baek, D.-Y.; Park, J.-H.; Cho, S.-C.; Lee, Y.-D. Rapid detection of shiga-toxin producing E. coli by bacteriophage amplification assay. Korean J. Food Sci. Technol. 2020, 52, 103-108.

3. Yoo, J.H.; Baek, K.H.; Heo, Y.S.; Yong, H.I.; Jo, C. Synergistic bactericidal effect of clove oil and encapsulated atmospheric pressure plasma against Escherichia coli O157:H7 and Staphylococcus aureus and its mechanism of action. Food Microbiol. 2021, 93, 103611. [CrossRef] [PubMed]

4. Xiang, Q.; Kang, C.; Zhao, D.; Niu, L.; Liu, X.; Bai, Y. Influence of organic matters on the inactivation efficacy of plasma-activated water against E. coli O157:H7 and S. aureus. Food Control 2019, 99, 28-33. [CrossRef]

5. Chen, X.; Hung, Y.-C. Effects of organic load, sanitizer $\mathrm{pH}$ and initial chlorine concentration of chlorine-based sanitizers on chlorine demand of fresh produce wash waters. Food Control 2017, 77, 96-101. [CrossRef] 
6. Jung, S.-J.; Park, S.Y.; Ha, S.-D. Synergistic effect of X-ray irradiation and sodium hypochlorite against Salmonella enterica serovar typhimurium biofilms on quail eggshells. Food Res. Int. 2018, 107, 496-502. [CrossRef] [PubMed]

7. Cao, W.; Zhu, Z.W.; Shi, Z.X.; Wang, C.Y.; Li, B.M. Efficiency of slightly acidic electrolyzed water for inactivation of Salmonella enteritidis and its contaminated shell eggs. Int. J. Food Microbiol. 2009, 130, 88-93. [CrossRef] [PubMed]

8. Ovissipour, M.; Al-Qadiri, H.M.; Sablani, S.S.; Govindan, B.N.; Al-Alami, N.; Rasco, B. Efficacy of acidic and alkaline electrolyzed water for inactivating Escherichia coli O104:H4, Listeria monocytogenes, Campylobacter jejuni, Aeromonas hydrophila, and Vibrio parahaemolyticus in cell suspensions. Food Control 2015, 53, 117-123. [CrossRef]

9. Huang, Y.; Chen, H. Effect of organic acids, hydrogen peroxide and mild heat on inactivation of Escherichia coli O157:H7 on baby spinach. Food Control 2011, 22, 1178-1183. [CrossRef]

10. Lee, S.Y.; Rhee, M.S.; Dougherty, R.H.; Kang, D.H. Antagonistic effect of acetic acid and salt for inactivating Escherichia coli O157:H7 in cucumber puree. J. Appl. Microbiol. 2010, 108, 1361-1368. [CrossRef]

11. Qian, J.; Zhuang, H.; Nasiru, M.M.; Muhammad, U.; Zhang, J.; Yan, W. Action of plasma-activated lactic acid on the inactivation of inoculated Salmonella Enteritidis and quality of beef. Innov. Food Sci. Emerg. Technol. 2019, 57, 102196. [CrossRef]

12. Fan, W.; An, W.-G.; Huo, M.-X.; Yang, W.; Zhu, S.-Y.; Lin, S.-S. Solubilization and stabilization for prolonged reactivity of ozone using micro-nano bubbles and ozone-saturated solvent: A promising enhancement for ozonation. Sep. Purif. Technol. 2020, 238, 116484. [CrossRef]

13. Lee, I.; Lee, E.; Lee, H.; Lee, K. Removal of COD and color from anaerobic digestion effluent of livestock wastewater by advanced oxidation using microbubbled ozone. Appl. Chem. Eng. 2011, 22, 617-622.

14. Ke, Z.; Chen, Z.; Huang, Q. Effect of chloride on bacterial inactivation by discharge plasma at the gas-solution interface: Potentiation or attenuation? Plasma Process Polym. 2018, 15, e1700153. [CrossRef]

15. Lin, C.-M.; Chu, Y.-C.; Hsiao, C.-P.; Wu, J.-S.; Hsieh, C.-W.; Hou, C.-Y. The optimization of plasma-activated water treatments to inactivate Salmonella Enteritidis (ATCC 13076) on shell eggs. Foods 2019, 8, 520. [CrossRef]

16. Zhao, Y.; Chen, R.; Tian, E.; Liu, D.; Niu, J.; Wang, W.; Qi, Z.; Xia, Y.; Song, Y.; Zhao, Z. Plasma-activated water treatment of fresh beef: Bacterial inactivation and effects on quality attributes. IEEE Trans. Radiat. Plasma Med. Sci. 2018, 4, 113-120. [CrossRef]

17. Zhou, R.; Zhou, R.; Wang, P.; Xian, Y.; Mai-Prochnow, A.; Lu, X.; Cullen, P.J.; Ostrikov, K.K.; Bazaka, K. Plasma-activated water: Generation, origin of reactive species and biological applications. J. Phys. D Appl. Phys. 2020, 53, 303001. [CrossRef]

18. Lukes, P.; Dolezalova, E.; Sisrova, I.; Clupek, M. Aqueous-phase chemistry and bactericidal effects from an air discharge plasma in contact with water: Evidence for the formation of peroxynitrite through a pseudo-second-order post-discharge reaction of $\mathrm{H}_{2} \mathrm{O}_{2}$ and $\mathrm{HNO}_{2}$. Plasma Sources Sci. Technol. 2014, 23, 015019. [CrossRef]

19. Machala, Z.; Tarabová, B.; Sersenová, D.; Janda, M.; Hensel, K. Chemical and antibacterial effects of plasma activated water: Correlation with gaseous and aqueous reactive oxygen and nitrogen species, plasma sources and air flow conditions. J. Phys. D Appl. Phys. 2019, 52, 034002. [CrossRef]

20. Burns, J.M.; Cooper, W.J.; Ferry, J.L.; King, D.W.; DiMento, B.P.; McNeill, K.; Miller, C.J.; Miller, W.L.; Peake, B.M.; Rusak, S.A.; et al. Methods for reactive oxygen species (ROS) detection in aqueous environments. Aquat. Sci. 2012, 74, 683-734. [CrossRef]

21. Ma, M.; Zhang, Y.; Lv, Y.; Sun, F. The key reactive species in the bactericidal process of plasma activated water. J. Phys. D Appl. Phys. 2020, 53, 185207. [CrossRef]

22. Møller, I.M.; Jensen, P.E.; Hansson, A. Oxidative modifications to cellular components in plants. Annu. Rev. Plant Biol. 2007, 58, 459-481. [CrossRef] [PubMed]

23. Huo, Z.-Y.; Li, G.-Q.; Yu, T.; Lu, Y.; Sun, H.; Wu, Y.-H.; Yu, C.; Xie, X.; Hu, H.-Y. Impact of water quality parameters on bacteria inactivation by low-voltage electroporation: Mechanism and control. Environ. Sci. Water Res. Technol. 2018, 4, 872-881. [CrossRef]

24. Jo, H.-Y.; Tango, C.N.; Oh, D.-H. Influence of different organic materials on chlorine concentration and sanitization of slightly acidic electrolyzed water. LWT Food Sci. Technol. 2018, 92, 187-194. [CrossRef] 
25. Baek, K.H.; Yong, H.I.; Yoo, J.H.; Kim, J.W.; Byeon, Y.S.; Lim, J.; Yoon, S.Y.; Ryu, S.; Jo, C. Antimicrobial effects and mechanism of plasma activated fine droplets produced from arc discharge plasma on planktonic Listeria monocytogenes and Escherichia coli O157:H7. J. Phys. D Appl. Phys. 2020, 53, 124002. [CrossRef]

26. Hong, Y.C.; Huh, J.Y.; Ma, S.H.; Kim, K.I. Inactivation of microorganisms by radical droplets from combination of water discharge and electro-spraying. J. Electrost. 2018, 91, 56-60. [CrossRef]

27. Ma, S.; Kim, K.; Huh, J.; Hong, Y. Characteristics of microdischarge plasma jet in water and its application to water purification by bacterial inactivation. Sep. Purif. Technol. 2017, 188, 147-154. [CrossRef]

28. Liu, Y.; Zhang, H.; Sun, J.; Liu, J.; Shen, X.; Zhan, J.; Zhang, A.; Ognier, S.; Cavadias, S.; Li, P. Degradation of aniline in aqueous solution using non-thermal plasma generated in microbubbles. Chem. Eng. J. 2018, 345, 679-687. [CrossRef]

29. Zhou, R.; Zhou, R.; Wang, P.; Luan, B.; Zhang, X.; Fang, Z.; Xian, Y.; Lu, X.; Ostrikov, K.K.; Bazaka, K. Microplasma bubbles: Reactive vehicles for biofilm dispersal. ACS Appl. Mater. Interfaces 2019, 11, 20660-20669. [CrossRef]

30. APHA. APHA Method 4500-O 3 . In Standard Methods for the Examination of Water and Wastewater, 18th ed.; Greenberg, A.E., Clesceri, L.S., Eaton, A.D., Eds.; American Public Health Association: Washington, DC, USA, 1992; pp. 105-107.

31. Wu, V.C.H.; Fung, D.Y.C. Evaluation of thin agar layer method for recovery of heat-injured foodborne pathogens. J. Food Sci. 2001, 66, 580-583. [CrossRef]

32. Aboubakr, H.A.; Gangal, U.; Youssef, M.M.; Goyal, S.M.; Bruggeman, P.J. Inactivation of virus in solution by cold atmospheric pressure plasma: Identification of chemical inactivation pathways. J. Phys. D Appl. Phys. 2016, 49, 204001. [CrossRef]

33. Guo, L.; Xu, R.; Gou, L.; Liu, Z.; Zhao, Y.; Liu, D.; Zhang, L.; Chen, H.; Kong, M.G. Mechanism of virus inactivation by cold atmospheric-pressure plasma and plasma-activated water. Appl. Environ. Microbiol. 2018, 84, e00726-18. [CrossRef] [PubMed]

34. Kim, T.; Seo, H.; Bae, H.; Kim, T.; Yang, S.; Moon, E. Generation of active species and antimicrobial efficacy of an underwater plasma device equipped with a porous bubbler. Plasma Process Polym. 2018, 15, e1700229. [CrossRef]

35. Yong, H.I.; Han, M.; Kim, H.-J.; Suh, J.-Y.; Jo, C. Mechanism underlying green discolouration of myoglobin induced by atmospheric pressure plasma. Sci. Rep. 2018, 8, 9790. [CrossRef]

36. Park, S.; Choe, W.; Jo, C. Interplay among ozone and nitrogen oxides in air plasmas: Rapid change in plasma chemistry. Chem. Eng. Trans. 2018, 352, 1014-1021. [CrossRef]

37. Puyate, Y.T.; Rim-Rukeh, A. Biocidal efficacy of dissolved ozone, formaldehyde and sodium hypochlorite against total planktonic microorganisms in produced water. J. Appl. Sci. 2008, 8, 860-865. [CrossRef]

38. Skowron, K.; Wałecka-Zacharska, E.; Grudlewska, K.; Białucha, A.; Wiktorczyk, N.; Bartkowska, A.; Kowalska, M.; Kruszewski, S.; Gospodarek-Komkowska, E. Biocidal effectiveness of selected disinfectants solutions based on water and ozonated water against Listeria monocytogenes strains. Microorganisms 2019, 7, 127. [CrossRef]

39. Chung, J.-W.; Park, J.-W.; Lee, C.-S. Effects of operating parameters on dissolved ozone and phenol degradation in ozone contact reactor. J. Korean Soc. Environ. Eng. 2010, 32, 241-247.

40. Silva, L.M.D.; Jardim, W.F. Trends and strategies of ozone application in environmental problems. Quim. Nova 2006, 29, 310-317. [CrossRef]

41. Tarr, M.; Valenzeno, D.P. Singlet oxygen: The relevance of extracellular production mechanisms to oxidative stress in vivo. Photochem. Photobiol. Sci. 2003, 2, 355-361. [CrossRef]

Publisher's Note: MDPI stays neutral with regard to jurisdictional claims in published maps and institutional affiliations. 